\title{
Modification of Hemoglobin H Disease by Sickle Trait
}

\author{
Katherine K. Matthay, William C. Mentzer, Jr., Andree M. Dozy, \\ Yuet Wai Kan, and Dorothy F. Bainton, Departments of Pediatrics, Medicine, \\ and Pathology, University of California, San Francisco, San Francisco, \\ California 94143
}

A B S T RAC T The rarity of hemoglobin $(\mathrm{Hb}) \mathrm{H}$ disease in combination with sickle trait may be due in part to the absence of actual $\mathrm{Hb} \mathrm{H}$ in individuals who, nonetheless, have inherited the deletion of three $\alpha$-globin genes. We describe here a boy with persistent microcytic, hypochromic anemia despite adequate iron stores, who exhibited splenomegaly with a normal reticulocyte count and only rare inclusions in circulating erythrocytes. Starch gel electrophoresis and isoelectric focusing at age $5 \mathrm{yr}$ showed $21 \% \mathrm{Hb} \mathrm{S}$, persistent $\mathrm{Hb}$ Bart's, but no $\mathrm{Hb} \mathrm{H}$. Recticulocyte $\alpha /$ non- $\alpha$ globin chain synthesis ratio was 0.58 at age 5 . The mother (Asian) had laboratory evidence of $\alpha$-thalassemia trait and the father (Black) had sickle trait. The nature of $\alpha$-thalassemia in this patient was investigated both by liquid hybridization and by the Southern method of gene mapping, in which DNA is digested with restriction endonucleases and the DNA fragments that contained the $\alpha$-globin structural gene identified by hybridization with complementary DNA. The patient had only one $\alpha$-globin structural gene, located in a DNA fragment shorter than that found in normal or $\alpha$-thalassemia trait individuals, but similar to that present in other patients with $\mathrm{Hb} \mathrm{H}$ disease. Morphologic studies of bone marrow by light and electron microscopy revealed erythroid hyperplasia with inclusions in polychromatic and orthochromatic erythroblasts, suggesting early precipitation of an unstable hemoglobin. The lack of demonstrable $\mathrm{Hb} \mathrm{H}$ may be the result of both diminished amounts of $\beta^{\mathrm{A}}$ available for $\mathrm{Hb} \mathrm{H}$ formation (since one $\beta$-globin gene is $\beta^{\mathrm{S}}$ ) and the greater affinity of $\alpha$-chains for $\beta^{\mathrm{A}}$ than $\beta^{\mathrm{S}}$-globin chains leading to the formation of relatively more $\mathrm{Hb} \mathrm{A}$ than $\mathrm{Hb} \mathrm{S}$. The pres-

This work was presented in part to the American Society of Hematology, New Orleans, La., December 1978.

Dr. Kan is an investigator of the Howard Hughes Medical Institute. Dr. Mentzer is the recipient of a U.S. Public Health Service Research Career Development Award.

Received for publication 9 April 1979 and in revised form 8 June 1979. ence of a $\beta^{\mathrm{S}}$ gene may thus modify the usual clinical expression of $\mathrm{Hb} \mathrm{H}$ disease.

\section{INTRODUCTION}

Simultaneous inheritance of $\alpha$-thalassemia and structural abnormalities of the $\beta$-chain frequently modifies the usual clinical expression of the $\beta$-globin mutation $(1-13)$. For example, observation of the nature of sickle cell anemia in several individuals who have also inherited $\alpha$-thalassemia trait has suggested in some cases (4-6), but not all $(7,8)$, a favorable effect of the $\alpha$ thalassemia gene on the clinical severity of sickle cell anemia. $\alpha$-Thalassemia with sickle cell trait consistently results in a lower than usual percentage of hemoglobin ( $\mathrm{Hb}) \mathrm{S}(9-13)$. We have investigated a child with sickle trait and microcytic anemia whose Asian mother had $\alpha$-thalassemia trait and whose Black father had sickle trait. The very low percentage of $\mathrm{Hb} \mathrm{S}$ suggested that both $\alpha$-thalassemia trait and sickle cell trait were present, but the presence of splenomegaly, extreme microcytosis, and bizarre erythrocyte morphology, features not seen in $\alpha$-thalassemia trait, stimulated further investigation.

Analysis of DNA from this child by molecular hybridization and gene-mapping techniques revealed that three of the four $\alpha$-globin genes normally found were deleted, thus unequivocally demonstrating the presence of the $\mathrm{Hb} \mathrm{H}$ genotype. Paradoxically, $\mathrm{Hb} \mathrm{H}$ was not identified in hemolysate from either peripheral blood or bone marrow, although inclusion bodies could be found in occasional erythrocytes in both places. The biochemical nature of these inclusions was not determined, but the appearance in early erythroid progenitors suggested a greater degree of instability than that associated with $\mathrm{Hb} \mathrm{H} \mathrm{(14-16).} \mathrm{This} \mathrm{patient,} \mathrm{who}$ represents the unusual coincidence of $\mathrm{Hb} \mathrm{H}$ disease with sickle trait, demonstrates how the inheritance of a $\beta$-globin structural mutation can modify the phenotype of $\mathrm{Hb} \mathrm{H}$ disease sufficiently to alter the usual clinical 
picture. In such patients, accurate genetic analysis is impossible unless the new techniques of molecular hybridization and gene mapping are used.

\section{METHODS}

Hematologic values. Hemoglobin levels and erythrocyte indices were obtained with a model S Coulter counter (Coulter Electronics Inc., Hialeah, Fla.). Bone marrow differential counts were performed by counting at least 500 cells. Cellulose acetate electrophoresis was performed in Tris-EDTAborate buffer at $\mathrm{pH} 8.4$ (17). $\mathrm{Hb} \mathrm{A}_{2}$ was determined by microchromatography (18). Fetal hemoglobin was determined by alkali denaturation (19). $\mathrm{Hb} \mathrm{H}$ preparations were made by mixing one part of fresh whole blood with two parts of $1 \%$ brilliant cresyl blue $(\mathrm{BCB})^{1}$ in $0.9 \% \mathrm{NaCl}$ and incubating at $37^{\circ} \mathrm{C}$ for $1-3 \mathrm{~h}$.

Hemoglobin and globin analyses. Globin chain synthesis was measured in vitro with fresh heparinized peripheral blood or bone marrow, as described by Kan et al. (20). L- $\left[{ }^{3} \mathrm{H}\right]$ leucinelabeled globin chains precipitated from cell-free hemolysate were separated on carboxymethyl cellulose columns in $8 \mathrm{M}$ urea at pH 7.2 using a linear $\mathrm{Na}_{2} \mathrm{HPO}_{4}$ gradient. The relative synthesis of $\alpha$-chain to $\beta$ - and $\gamma$-chain was expressed as the ratio of the total radioactivity of the $\alpha$ - to non- $\alpha$-globin peaks. Starch gel electrophoresis was carried out at $4^{\circ} \mathrm{C}$ for $3 \mathrm{~h}$ at $25 \mathrm{~mA}$ and $200 \mathrm{~V}$ according to the method of Smithies (21) with

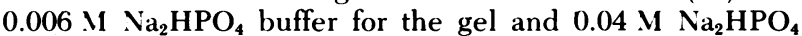
buffer for the electrodes, both at $\mathrm{pH}$ 7.0. The gel was then sliced horizontally and stained with benzidine.

Thin-layer isoelectric focusing in polyacrylamide gel was carried out with fresh hemolysate according to Basset et al. (22). Hemoglobin column chromatography was performed on carboxymethyl cellulose (CM-52, Whatman, Inc., Clifton, N. J.) according to Schroeder et al. (23). 1-ml of stroma-free hemolysate was prepared from fresh peripheral blood or bone marrow and then dialyzed for $18 \mathrm{~h}$ against $0.01 \mathrm{M}$ Bistris [N,N-Bis-(2-hydroxymethyl)-iminotris-(hydroxymethyl)methane], pH 6.1 , plus $0.01 \% \mathrm{KCN}$. $50-60 \mathrm{mg}$ of dialyzed hemoglobin was applied to a $0.9 \times 20$-cm column equilibrated with the dialysis buffer. The hemoglobin was eluted with 0.03 $\mathrm{M}$ Bis-tris and $0.01 \% \mathrm{KCN}, \mathrm{pH} 6.1$, using a linear salt gradient $(0-0.08 \mathrm{M} \mathrm{NaCl}$, total volume, $1,200 \mathrm{ml})$ over $24 \mathrm{~h}$. The position of each eluted hemoglobin type was determined by recording the optical density at $415 \mathrm{~nm}$ of each fraction as a function of salt concentration, measured from conductance. To identify each hemoglobin eluted, two or three fractions from each peak were then pooled and centrifuged for $18 \mathrm{~h}$ at $50,000 \mathrm{rpm}$ in a Beckman ultracentrifuge (Beckman Instruments, Inc., Spinco Div., Palo Alto, Calif.) to concentrate the hemoglobin into a $0.5-\mathrm{ml}$ vol. Globin was then prepared from each concentrated portion by acid-acetone precipitation, lyophilized, then resuspended and electrophoresed on cellulose acetate in Bis-tris-EDTA-borate-urea buffer at $\mathrm{pH} 6.4$ according to the method of Salmon et al. (24). The strips were stained with Ponceau S and decolorized with $3 \%$ acetic acid.

Electron microscopy. Specimens of bone marrow and blood were immediately fixed in $1.5 \%$ buffered glutaraldehyde at $22^{\circ} \mathrm{C}$, postfixed in $\mathrm{OsO}_{4}$, and processed for examination by transmission electron microscopy, as described (25). Other samples were prepared for scanning electron microscopy by critical-point drying and coated with gold-platinum.

${ }^{1}$ Abbreviations used in this paper: BCB, brilliant cresyl blue; cDNA, complementary DNA; kb, kilobase pairs; $\mathrm{Hb}$, hemoglobin.
Liquid hybridization. DNA from the patient, his mother, and controls with hydrops fetalis, $\mathrm{Hb} \mathrm{H}$ disease, $\alpha$-thalassemia trait, and normals was prepared from leukocytes, liver, or spleen by sodium dodecyl sulfate-pronase digestion and phenol extraction. The RNA was digested with ribonuclease and the DNA reduced to $2 \times 10^{6}$ daltons by limited depurination $(26,27)$. $\alpha$-globin complementary DNA (cDNA) was prepared as described $(26,28)$. The $\alpha$-cDNA $(1,000 \mathrm{cpm})$ was incubated for $76 \mathrm{~h}$ at $78^{\circ} \mathrm{C}$ in duplicate 20 - $\mu$ l reaction mixtures containing $100 \mu \mathrm{g}$ cellular DNA, $8 \mathrm{pg} \alpha$-cDNA, $500 \mathrm{cpm}$ of $\left[{ }^{3} \mathrm{H}\right] \mathrm{dCTP}$-labeled unique sequence HeLa DNA as internal control, $0.5 \mathrm{M} \mathrm{NaCl}, 0.002 \mathrm{M}$ EDTA, and $0.04 \mathrm{M}$ Tris- $\mathrm{HCl}$ $(\mathrm{pH} 7.4)$. The percentage of $\alpha$-cDNA annealed was assayed by batchwise elution with hydroxylapatite (29).

Restriction endonuclease analysis of DNA. DNA was prepared from the leukocytes of the patient, his mother, $\alpha$-thalassemia trait, silent carrier, $\mathrm{Hb} \mathrm{H}$ disease, and normal controls, as described (30). $10 \mu \mathrm{g}$ of human DNA and $1 \mu \mathrm{g}$ of $\lambda$-DNA (as internal size marker) were digested for $4 \mathrm{~h}$ at $37^{\circ} \mathrm{C}$ with $1.25 \mathrm{U}$ of Eco RI or Hpa I per microgram of DNA. The buffer for Eco RI digestion contained $100 \mathrm{mM}$ Tris- $\mathrm{HCl}(\mathrm{pH} \mathrm{7.5)}$, $50 \mathrm{mM} \mathrm{NaCl}, 6 \mathrm{mM} \mathrm{MgCl}_{2}$, and $6 \mathrm{mM}$ 2-mercaptoethanol, and for $\mathrm{HpaI}$ digestion, $6 \mathrm{mM}$ Tris- $\mathrm{HCl}$ (pH 7.5), $26 \mathrm{m.l} \mathrm{NaCl}$, $6 \mathrm{mM} \mathrm{M} \mathrm{Mgl}_{2}$, and $6 \mathrm{mM} \mathrm{2-mercaptoethanol.} \mathrm{The} \mathrm{samples}$ were precipitated in alcohol, dried and resuspended in $30 \mu \mathrm{l}$ of $5 \mathrm{mM}$ Tris ( $\mathrm{pH} 7.5$ ), $0.1 \mathrm{mM}$ EDTA. The digested DNA's were electrophoresed in $0.8 \%$ agarose and then transferred to nitrocellulose filters (31). The filters were hybridized with ${ }^{32} \mathrm{P}$-labeled $\alpha$ - and $\beta$-globin cDNA $\left(2 \times 10^{8} \mathrm{cpm} / \mu \mathrm{g}\right)$ for $2 \mathrm{~d}$ and extensively washed and autoradiographed, as described (30).

\section{RESULTS}

Case report. S.H. is a 5 9/12-yr-old Black/Chinese male with marked microcytic anemia in the presence of adequate iron stores. Physical examination has been notable for persistent splenomegaly. Hematologic data obtained over a 5-yr period of observation are shown in Table I. Erythrocyte morphology has consistently resembled that of $\mathrm{Hb} \mathrm{H}$ disease, with hypochromia, poikilocytosis, fragments, spherocytes, and target cells evident on the peripheral blood smear (Fig. $1 \mathrm{~A}$ and B). $\mathrm{BCB}$ stains revealed no $\mathrm{Hb} \mathrm{H}$ inclusions in the circulating erythrocytes at age 1 or $2 \mathrm{yr}$. An occasional inclusion-containing cell was evident at age $5 \mathrm{yr}$ (Fig. 1C and D). Hemoglobin electrophoresis has been consistent with sickle trait, but with an unusually low percentage of $\mathrm{Hb} \mathrm{S}$, persistence of $\mathrm{Hb}$ Bart's and elevated $\mathrm{Hb} \mathbf{F}$ (Table I). Bone marrow aspirate and biopsy showed erythroid hyperplasia (myeloid:erythroid ratio, $1: 2$ ), a finding in apparent contradiction to the repeatedly normal reticulocyte count. The percentage of early erythroid precursors (proerythroblasts, 5\%; basophilic erythroblasts, 22\%) was markedly increased, while polychromatophilic and orthochromatic erythroblasts were present in normal numbers. Methyl violet and BCB stains of the bone marrow showed the same frequency of hemoglobin inclusions as in the peripheral blood. Family studies confirmed that the Black 
TABLE I

Hematologic Data in Hb H Disease with Sickle Trait

\begin{tabular}{|c|c|c|c|c|c|}
\hline & \multicolumn{3}{|c|}{ Patient } & \multirow{2}{*}{$\begin{array}{l}\text { Mother } \\
\text { (Asian) }\end{array}$} & \multirow{2}{*}{$\begin{array}{l}\text { Father } \\
\text { (Black) }\end{array}$} \\
\hline & $10 \mathrm{mo}$ & $31 \mathrm{mo}$ & $60 \mathrm{mo}$ & & \\
\hline $\mathrm{Hb}, g / d l$ & 9.4 & 9.3 & 9.4 & 11.3 & 13.6 \\
\hline PCV & 0.29 & 0.29 & 0.27 & 0.34 & 0.39 \\
\hline $\mathrm{MCH}, p g$ & 16.9 & 16.0 & 17.0 & 22.0 & 29.8 \\
\hline $\mathrm{MCHC}, \mathrm{g} / d \mathrm{l}$ & 33.3 & 31.9 & 33.8 & 33.0 & 35.1 \\
\hline $\mathrm{MCV}, f$ & 50 & 50 & 51 & 70 & 86 \\
\hline Erythrocyte, $\times 10^{12} /$ liter & 5.67 & 5.85 & 5.50 & 4.90 & 4.52 \\
\hline Retic, \% & 0.6 & 0.7 & 0.9 & 1.0 & 1.4 \\
\hline $\mathrm{Fe} / \mathrm{TIBC}, \mu m / l i t e r$ & $18.5 / 80.8$ & $15.7 / 61.7$ & - & - & - \\
\hline \multicolumn{6}{|c|}{ Hemoglobin electrophoresis* } \\
\hline $\mathrm{Hb} \mathrm{A}, \%$ & 65.9 & 70.4 & 71.8 & 96.9 & 64.3 \\
\hline $\mathrm{A}_{2}, \%$ & 3.1 & 1.9 & 3.2 & 2.5 & 2.5 \\
\hline $\mathrm{S}, \%$ & 17.3 & 20.1 & 21.0 & 0 & 32.6 \\
\hline $\mathrm{F}, \%$ & 10.3 & 4.6 & 4.0 & 0.6 & 0.6 \\
\hline Hb Bart's, \% & 3.4 & 3.0 & Trace & 0 & 0 \\
\hline \multicolumn{6}{|l|}{ Globin synthesis ratio } \\
\hline$\alpha /(\beta+\gamma)$ & $0.92 \$$ & $0.65 \ddagger$ & $0.58 \ddagger$ & $0.88 \ddagger$ & - \\
\hline & & & $0.96 \$$ & & \\
\hline
\end{tabular}

Abbreviations used in this table: $\mathrm{PCV}$, packed cell volume or hematocrit; $\mathrm{MCH}$, mean corpuscular hemoglobin; MCHC, MCH concentration; MCV, mean corpuscular volume; TIBC, total iron binding capacity.

* Relative hemoglobin percentages determined by densitometric scan of cellulose acetate strip, as well as separate quantitation of $\mathrm{Hb} \mathrm{A}_{2}$ and $\mathrm{Hb} \mathrm{F}$.

$\ddagger$ Peripheral blood.

$\S$ Bone marrow.

father had sickle trait, whereas the Asian mother had the hematologic features of $\alpha$-thalassemia trait (Table I).

Globin chain synthesis. The reduced $\alpha /(\beta+\gamma)$ globin chain synthetic ratios in peripheral blood reticulocytes and bone marrow of the patient, shown in Table I, were consistent with either $\alpha$-thalassemia trait or $\mathrm{Hb} \mathrm{H}$ disease (32). $\beta^{\mathrm{A}}: \beta^{\mathrm{S}}$ activity ratios were $6: 1,4: 1$, and $3: 1$ at 10,31 , and 60 mo, respectively. The bone marrow $\beta^{\mathrm{A}}: \beta^{\mathrm{S}}$ activity $(2: 1)$ was more nearly normal. The mother's peripheral blood $\alpha / \beta$-globin chain synthetic ratio was 0.88 , consistent with $\alpha$-thalassemia trait.

Hemoglobin analyses. Starch gel electrophoresis of hemolysate obtained from peripheral blood, shown in Fig. 2, revealed a trace amount of $\mathrm{Hb}$ Bart's. No $\mathrm{Hb} \mathrm{H}$ or other abnormal fast hemoglobins were found. Thinlayer isoelectric focusing also showed only hemoglobins Bart's, A, F, S, and $\mathrm{A}_{2}$. Column chromatography, (Fig. 3) also failed to detect measurable amounts of $\mathrm{Hb} \mathrm{H}$ or other fast hemoglobins, except for $\mathrm{Hb}$ Bart's. Globin electrophoresis was used to confirm the identity of each hemoglobin eluted. The first peak eluted contained $\gamma$-chains; the second, $\alpha$ - and $\gamma$-chains; the small shoulder and the third peak contained $\alpha$ and $\beta^{\mathrm{A}}$; the fourth, $\alpha$ and $\delta$; and the last peak, $\alpha$ and $\beta^{\mathrm{s}}$. $\beta^{\mathrm{s}}$-chains were found only in the $\mathrm{Hb} \mathrm{S}$ fraction, ruling out the possibility that $\beta_{4}^{\mathrm{S}}$ tetramers were present elsewhere, but hidden because they eluted with another hemoglobin. Only the Hb Bart's fraction was composed of a single globin chain, which migrated to the $\gamma$ position, as expected. Hemoglobin analysis of a bone marrow hemolysate by starch gel and column chromatography gave virtually identical results to those found in peripheral blood. The bone marrow percentages were $\mathrm{Hb}$ Bart's, $1.4 \%$; $\mathrm{Hb} \mathrm{F}, 6.1 \%$; $\mathrm{Hb} \mathrm{A}, 72.5 \%$; $\mathrm{Hb} \mathrm{A}_{2}, 3.6 \%$; and $\mathrm{Hb} \mathrm{S}, 16.4 \%$.

Electron microscopy of bone marrow. Numerous dense amorphous inclusions of varying sizes, comparable to those seen in the bone marrow of patients with $\beta$-thalassemia major $(33,34)$ were seen in reticulocytes and orthochromatic (Fig. 4A) and polychromatic erythroblasts (Fig. 4B). Although these were generally not membrane-bound (Fig. 4A), in a few instances they were contained within autophagic vacuoles (Fig. 4B), as has also been described in $\beta$-thalassemia $(33,35)$. The frequency of inclusions corresponded to that seen on methyl violet stain. Many of the mature erythrocytes appeared very thin and distorted, as can be seen in the scanning electron micrographs (Fig. 4C and D), because of poor hemoglobinization, a common finding 


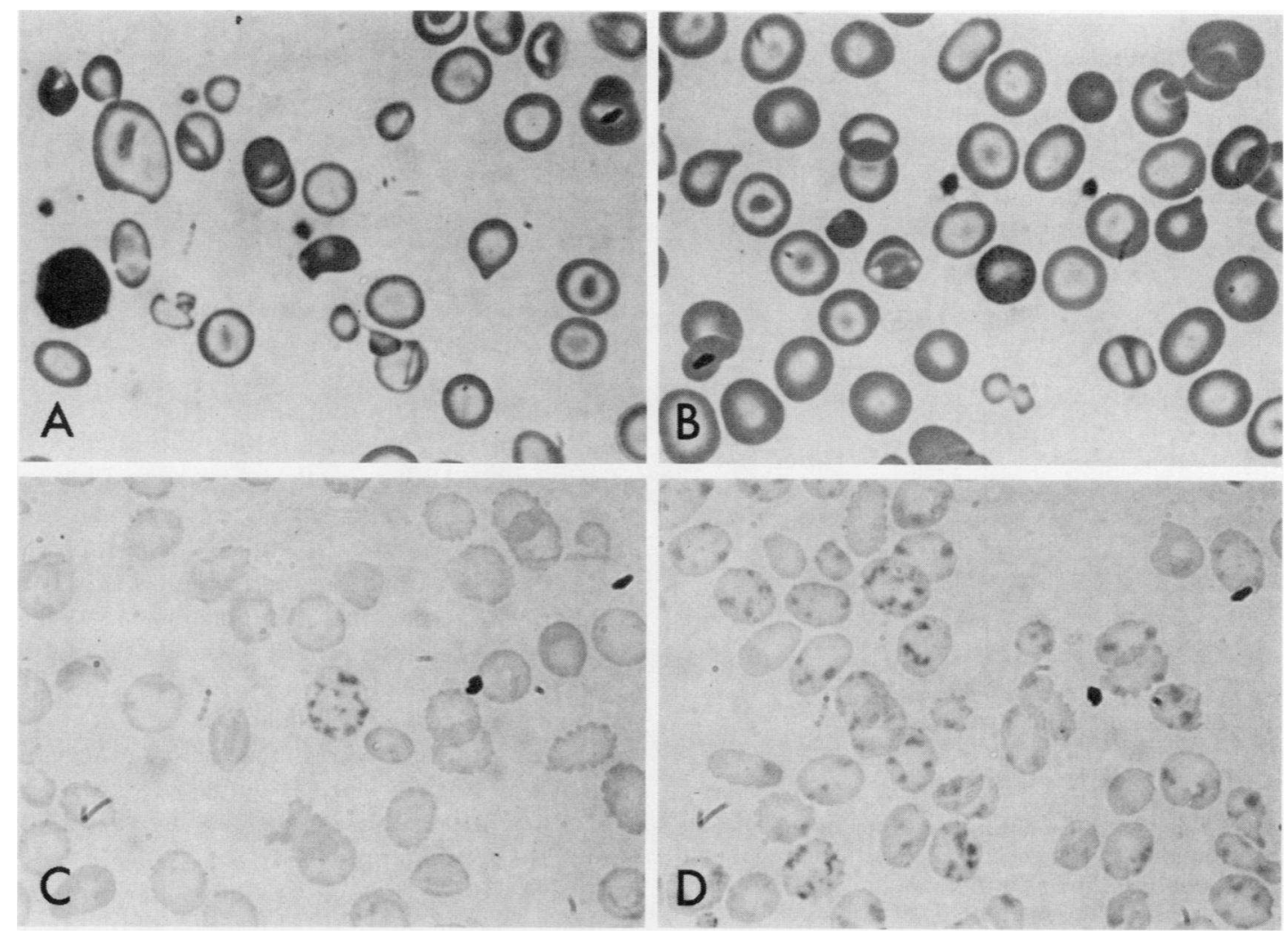

Figure 1 Peripheral blood (Wright's stain) of Propositus (A) and of individual with $\mathrm{Hb} \mathrm{H}$ disease (B). Peripheral blood (BCB stain) of Propositus (C) showing occasional (1/125) erythrocytes contain inclusions and of individual with $\mathrm{Hb} \mathrm{H}$ disease (D) showing inclusions in almost every erythrocyte.

in thalassemia (34). Occasionally small pits (Fig. 4C) could be detected. Similar pitting of erythrocytes has previously been noted with Nomarski optics in individuals with $\mathrm{Hb} \mathrm{H}$ disease, even those with intact spleens (14).

$\alpha$-Globin-cDNA liquid hybridization. Because hematological, family, and globin chain synthesis

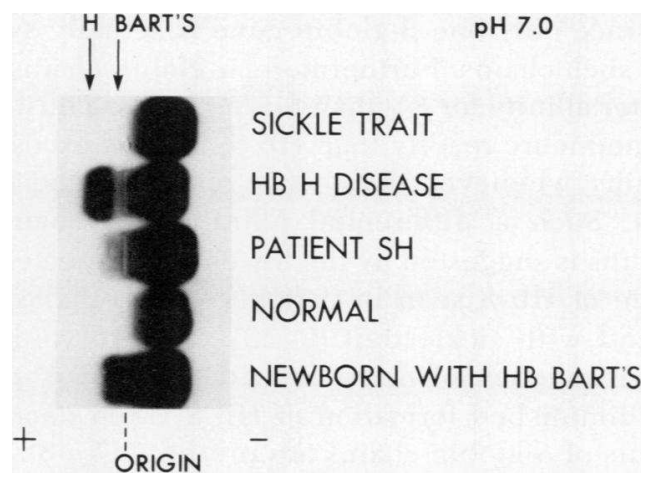

FIGURE 2 Starch gel hemoglobin electrophoresis at pH 7.0. The patient has hemoglobin Bart's, as well as A, F, and S. studies were inconclusive, additional studies were done to analyze the $\alpha$-globin genes directly. Fig. 5 shows the percent annealing of ${ }^{32} \mathrm{P}$-labeled $\alpha$-globin cDNA to DNA from the propositus, his mother, and controls. DNA from the patient showed the same percent annealing as six Asian $\mathrm{Hb} \mathrm{H}$ disease controls, who lack three of four $\alpha$-globin genes. His mother showed the same percentage of $\alpha$-sequences as other $\alpha$-thalassemia trait individuals with a deletion of two of the four $\alpha$-globin genes.

Restriction endonuclease analysis of DNA. Figs. 6 and 7 show the diagrammatic and autoradiographic results of DNA digested with Eco RI and Hpa I and hybridized with cDNA. The $\alpha$-globin specific fragment in DNA from the patient was smaller than normal after Eco RI digestion and was identical to the 19-kilobase pairs (kb) $\alpha$-specific DNA of known $\mathrm{Hb} \mathrm{H}$ disease controls. The patient was lacking the $4.0-\mathrm{kb}$ fragment after Hpa I digestion, one of the two $\alpha$-specific fragments normally present, again corresponding to known $\mathrm{Hb} \mathrm{H}$ disease controls. The autoradiogram of hybridized $\alpha$ globin DNA from the patient's mother was identical to the pattern of controls with $\alpha$-thalassemia trait. The patient's father was not available for testing. 


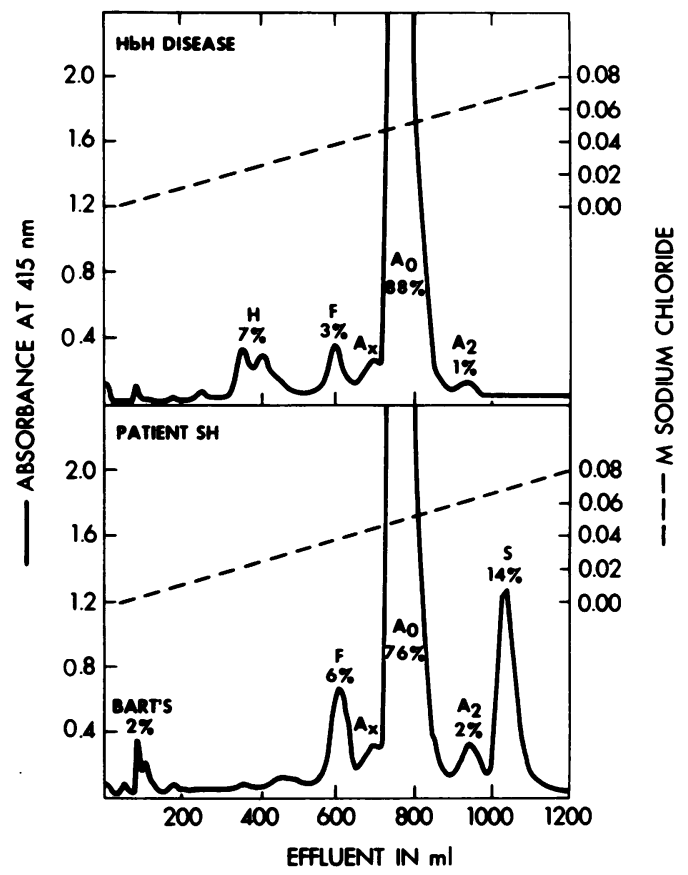

FIGURE 3 Carboxymethyl cellulose chromatography of hemoglobin. The identity of each peak was confirmed with globin electrophoresis, including the $A_{x}$ fraction (the small peak eluted just before the main hemoglobin A peak), which contained $\alpha$ - and $\beta^{\mathrm{A}}$-globin chains.

\section{DISCUSSION}

This patient was investigated because of many clinical findings that did not conform with the usual features of $\alpha$-thalassemia trait with sickle trait. The presence of splenomegaly, anemia, marked microcytosis and strikingly abnormal erythrocyte morphology all suggested a more severe $\alpha$-chain deficiency, such as $\mathrm{Hb} \mathrm{H}$ disease, rather than $\alpha$-thalassemia trait. However, the normal reticulocyte count, the absence of $\mathrm{Hb} \mathrm{H}$ in hemolysates, and the paucity of inclusions in circulating erythrocytes were not characteristic of $\mathrm{Hb} \mathrm{H}$ disease. The possibility that $\mathrm{Hb} \mathrm{H}$ was absent as a result of severe iron deficiency (36) was ruled out by repeatedly normal serum and bone marrow iron studies.

Although the globin chain synthesis studies demonstrated deficient $\alpha$-chain production, the results were consistent with either a two gene or three gene deletion (32). A decreasing $\alpha /$ non- $\alpha$ ratio with increasing age, as seen in the propositus, has been previously noted in patients with $\alpha$-thalassemia (37) and may be related to the switch from fetal to adult hemoglobin production. No ready explanation is apparent for the decreasing $\beta^{\mathrm{A}}: \beta^{\mathrm{S}}$ ratio noted with age. The more normal $\alpha /$ non- $\alpha$ chain ratio seen in bone marrow, as compared to peripheral blood, has also been reported in some patients with $\alpha$-thalassemia (38).
A more precise definition of the nature of the thalassemia defect was obtained by molecular hybridization studies. Liquid hybridization with $\alpha$-globin cDNA was clearly compatible with deletion of three $\alpha$-globin genes, the typical genotype of Asian $\mathrm{Hb} \mathrm{H}$ disease (27). Restriction endonuclease gene-mapping techniques also clearly delineated the presence of only a single $\alpha$-globin gene. It is important to note that $\alpha$ thalassemia trait, with deletion of the two $\alpha$-globin genes in trans, also results in a restriction endonuclease digest of two identical, but smaller than normal, $19 \mathrm{~kb} \alpha$-globin DNA fragments, like the Eco RI pattern seen in the patient and in other individuals with $\mathrm{Hb} \mathrm{H}$ disease (39). However, the patient could not have inherited $\alpha$-thalassemia trait in trans, since the DNA digest from the mother showed only a normal size $23 \mathrm{~kb}$ $\alpha$-globin DNA fragment, consistent with $c i s-\alpha$-thalassemia trait, where one chromosome has two intact $\alpha$ globin genes and the other is devoid of $\alpha$-globin genes. The patient, therefore, inherited his single intact $\alpha$ globin gene from his Black father, who presumably was a silent carrier of $\alpha$-thalassemia (genotype, $-\alpha / \alpha \alpha)$. The silent carrier state is actually quite common in Blacks, with a frequency of $24 \%$ by restriction endonuclease gene mapping (40).

$\mathrm{Hb} \mathrm{H}$ disease has never before been reported in a patient with sickle trait. Although the incidence of $\mathrm{Hb}$ $\mathrm{H}$ disease in Blacks is admittedly low (40-42), the apparent rarity of the combined defect may also be a result of the lack of a readily available means of detection, since $\mathrm{Hb} \mathrm{H}$ is not always present in measurable amounts. Although other patients with a $\beta$-chain abnormality and a suspected $\mathrm{Hb} \mathrm{H}$ genotype, but without $\beta_{4}^{\mathrm{A}}$ tetramers have been described $(1,5,14,43-46)$, direct demonstration of the $\alpha$-globin gene defect has not previously been possible.

There are several possible reasons that $\mathrm{Hb} \mathrm{H}$ disease, when inherited with the $\beta$-gene mutation of sickle trait, may produce a syndrome of hemolytic anemia without detectable $\beta$-globin tetramers. One is the decreased quantity of $\beta^{\mathrm{A}}$ globin chains available for $\mathrm{Hb} \mathrm{H}$ formation, since only one $\beta$-globin gene is actually synthesizing such chains. Furthermore, $\alpha$-globin chains have a greater affinity for $\beta^{\mathrm{A}}$ - than for $\boldsymbol{\beta}^{\mathrm{S}}$-chains. Thus, $\mathrm{Hb} \mathrm{A}$ is formed more readily than $\mathrm{Hb} S$, leaving excess free $\beta^{\mathrm{s}}$-chains whenever there is a relative deficit of $\alpha$ chains. Such a differential affinity of $\alpha$-chains for $\beta^{A}$-chains is suggested by the lower than expected percentage of $\mathrm{Hb} \mathrm{S}$ seen in patients with $\alpha$-thalassemia trait and with sickle trait $(9-13)$. In vitro studies of the reassociation of $\alpha$-chains with $\beta^{\mathrm{A}}$ - and $\beta^{\mathrm{S}}$-chains show diminished formation of $\mathrm{Hb} \mathrm{S}$ when decreased amounts of $\alpha$-globin chains are present $(47,48)$.

Despite the lack of detectable $\mathrm{Hb} \mathrm{H}$, our patient had evidence of erythrocyte destruction with frag- 

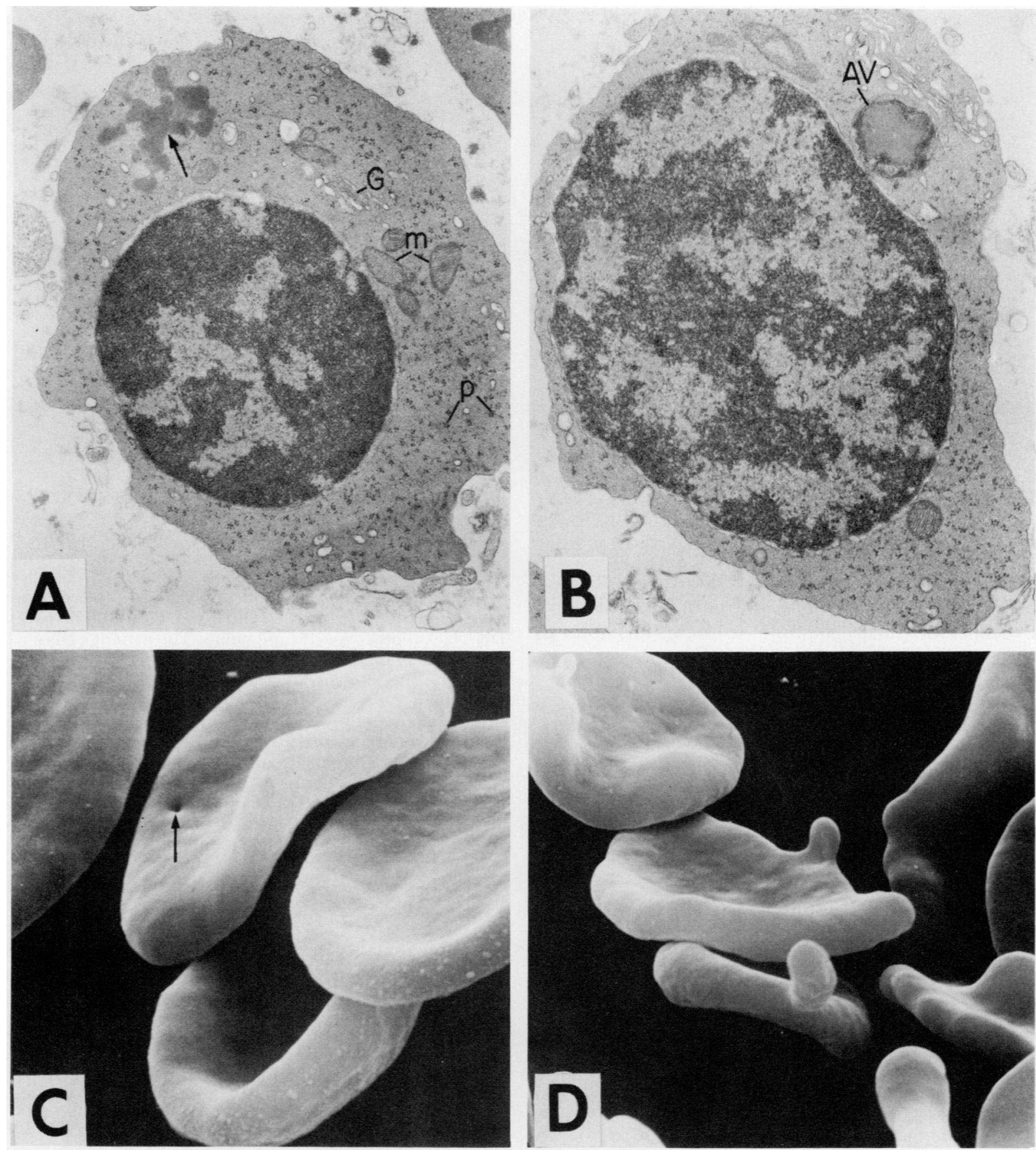

FIGURE 4 Transmission electron micrographs of developing erythroblasts from the bone marrow. (A) is an orthochromatic erythroblast and its cytoplasm contains abnormal amorphous inclusions (arrow). The nucleus and other organelles such as the Golgi complex (G), mitochondria $(\mathrm{m})$, and polyribosomes $(\mathrm{p})$ appear normal. $\times 15,000$. (B) is a polychromatic erythroblast which also contains similar inclusions but within a membrane-bound organelle, probably an autophagic vacuole (AV). $\times 18,000$. (C and D) Scanning electron micrographs of circulating blood erythrocytes. The cells are thinner than normal and there are many irregularities in shape. Note the knob-like projections in D. Occasional small pits (arrow) are evident. C, $\times 8,000 ; D, \times 7,200$. 


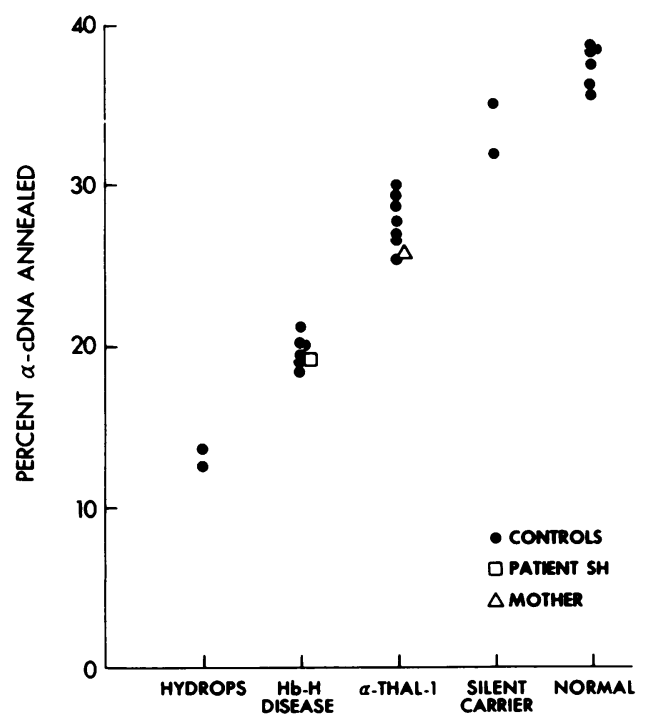

FIgURE 5 Liquid hybridization with $\left[\alpha^{-32} \mathrm{P}\right]$ globin cDNA.

mentation and splenomegaly, as well as ineffective erythropoiesis. It is possible that the excess $\beta^{\mathrm{s}}$-chain present in the bone marrow and peripheral blood of the propositus may combine to form unstable $\beta_{4}^{\mathrm{S}}$

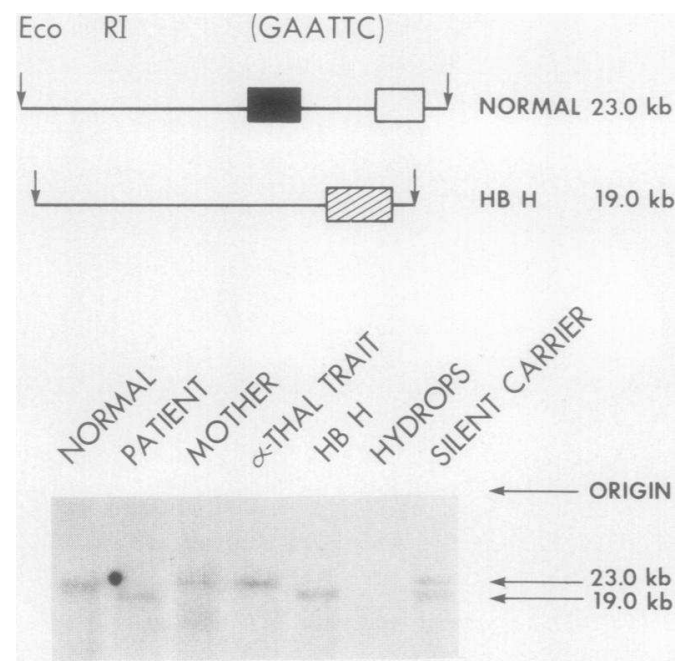

Figure 6 (A) Diagram representing the Eco RI restriction endonuclease cleavage sites of $\alpha$-globin DNA in the normal individual and a person with $\mathrm{Hb} \mathrm{H}$ disease. (B) Autoradiogram of Eco RI digestion pattern of DNA from patient, mother, and appropriate controls, using $\left[\alpha^{32} \mathrm{P}\right]$ globin cDNA as a probe. The normal DNA shows a single $23 \mathrm{~kb} \alpha$-specific fragment. The patient has a smaller $19 \mathrm{~kb}$ fragment, identical to the $\mathrm{Hb} \mathrm{H}$ control. The DNA of the mother shows the 23-kb fragment seen in the $\alpha$-thalassemia trait control, who has two $\alpha$-globin genes in cis on one chromosome, the other chromosome being devoid of $\alpha$-genes. The hydrops DNA has no $\alpha$ specific fragment, while the silent carrier of $\alpha$-thalassemia, with three out of four intact $\alpha$-globin genes, has both a normal $23 \mathrm{~kb}$ and a small $19 \mathrm{~kb}$ fragment.

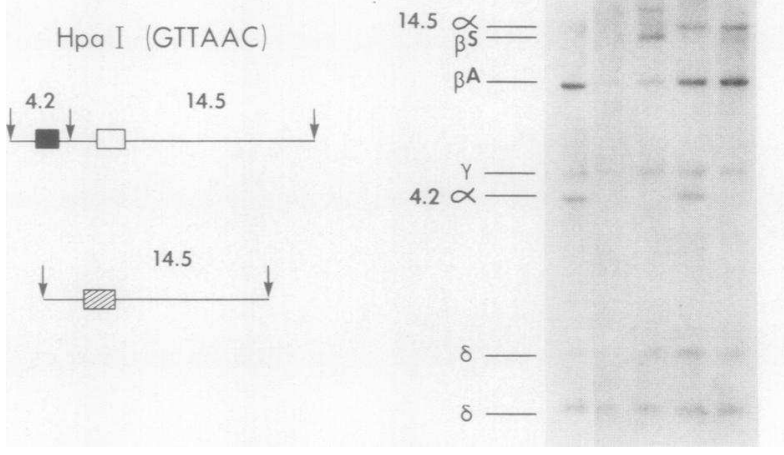

FiguRE 7 (A) Diagram representing Hpa I restriction endonuclease cleavage sites of $\alpha$-globin DNA in the normal and the individual with $\mathrm{Hb} \mathrm{H}$ disease. (B) Autoradiogram of $\mathrm{Hpa}$ I digestion in DNA from the patient, his mother, and controls using both $\alpha$-and $\beta$-cDNA as probes. The normal DNA has two $\alpha$-specific fragments of 4.0 and $14.5 \mathrm{~kb}$. The other fragments have been shown to be $\gamma$-, $\delta$-, and $\beta$-specific (30). The hydrops DNA lacks both $\alpha$-specific fragments. The patient's DNA lacks the smaller $4.0 \mathrm{~kb} \alpha$-specific fragment as does the $\mathrm{Hb} \mathrm{H}$ control. (The single $\alpha$-specific fragment in the patient's DNA is larger than the usual $14.5 \mathrm{~kb}$ fragment, but this corresponds to a variant $\alpha$-globin DNA fragment seen in some normal individuals without $\mathrm{Hb} \mathrm{H}$ disease, probably because of polymorphism of the $\alpha$-gene [Kan, Y. W., unpublished data]. The very faint band appearing in the 14.5-kb position is not $\alpha$ specific and was not present in a subsequent Hpa I digest of the patient's DNA.) The patient's DNA also contains a 13.0$\mathrm{kb} \beta$-specific fragment, which occurs in $80 \%$ of individuals with sickle hemoglobin (30). The mother's DNA has both $\alpha$ specific fragments, as seen in $\alpha$-thalassemia trait.

tetramers that then precipitate rapidly, resulting in loss of erythroid precursors in the bone marrow and destruction of precipitate-containing peripheral blood cells by the spleen. Alternatively, the excess $\beta^{\mathrm{s}}$-chain might bind to the erythrocyte membrane, causing damage and subsequent hemolysis, since preferential binding of $\beta^{\mathrm{s}}$ to stroma has been demonstrated (49). The presence of some type of unstable hemoglobin was indicated by the occasional inclusion-containing cells seen in both peripheral blood and bone marrow by special stains and electron microscopy. The electrophoretic and chromatographic techniques employed are not sufficiently sensitive to unequivocally rule out the possibility that these occasional inclusions are composed of $\mathrm{Hb} \mathrm{H}$. However, the distribution of these inclusions was not typical of $\mathrm{Hb} \mathrm{H}$ disease. $\beta_{4}^{\mathrm{A}}$ tetramers precipitate in mature erythroblasts and in peripheral erythrocytes (15) causing membrane pitting and rigidity with gradual extramedullary hemolysis, rather than ineffec- 
tive erythropoiesis. On the other hand, $\beta$-thalassemia is characterized by extensive ineffective erythropoiesis (14). Inclusions, presumably a result of unstable $\alpha$ chains, can be seen in the bone marrow in immature erythroblasts with methyl violet stains (50) or electron microscopy (14), but do not appear in peripheral blood except after splenectomy. The distribution of inclusions in our patient to some degree resembles both $\beta$-thalassemia and $\mathrm{Hb} \mathrm{H}$ disease. As in $\beta$-thalassemia, some inclusions are seen in the younger polychromatophilic erythroblasts, and may be responsible for rapid intramedullary hemolysis, as indicated by the large proportion of immature erythroid forms in the face of a low reticulocyte count. However, a few cells containing unstable hemoglobin do reach the peripheral blood (Fig. 1), where they are presumably destroyed in the spleen.

\section{ACKNOWLEDGMENTS}

We thank Dr. J. Rosa, Hopital Henri Mondor, Creteil, France, for kindly performing the thin-layer isoelectric focusing and Mr. Rick Trecartin for performing the globin chain synthesis studies and assisting with the column chromatography. We also gratefully acknowledge the secretarial assistance of Ms. Terry Tschopp.

This investigation was supported by grants from the National Institutes of Health (HL20985), the U. S. Public Health Service (5 K04 HL00086), and the National FoundationMarch of Dimes (6-49).

\section{REFERENCES}

1. Tuchinda, S., D. L. Rucknagel, V. Minnich, U. Boonyaprakob, K. Balankura, and V. Suvatee. 1964. The coexistence of the genes for hemoglobin $\mathrm{E}$ and $\alpha$ thalassemia in Thais, with resultant suppression of hemoglobin E synthesis. Am. J. Hum. Genet. 16: 311-335.

2. Honig, G. R., U. Gunay, R. G. Mason, L. N. Vida, and C. Ferenc. 1976. Sickle cell syndromes. I. Hemoglobin SC- $\alpha$-thalassemia. Pediatr. Res. 10: 613-620.

3. Kim, H. C., R. G. Weierbach, S. Friedman, and E. Schwartz. 1977. Globin biosynthesis in sickle cell, Hb SC, and $\mathrm{Hb} \mathrm{C}$ diseases. J. Pediatr. 91: 13-18.

4. Aksoy, M. 1963. The first observation of homozygous hemoglobin S-alpha thalassemia disease and two types of sickle cell thalassemia disease: (a) Sickle cell-alpha thalassemia disease, (b) Sickle cell-beta thalassemia disease. Blood. 22: 757-769.

5. Weatherall, D. J., J. B. Clegg, J. Blankson, and J. R. McNeil. 1969. A new sickling disorder resulting from interaction of the genes for haemoglobin $\mathrm{S}$ and $\alpha$-thalassaemia. Br. J. Haematol. 17: 517-526.

6. Van Enk, A., A. Lang, J. M. White, and H. Lehmann. 1972. Benign obstetric history in women with sickle-cell anaemia associated with $\alpha$-thalassaemia. Br. Med. J. 4: $524-526$.

7. Honig, G. R., M. Koshy, R. G. Mason, and L. N. Vida. 1978. Sickle cell syndromes. II. The sickle cell anemia$\alpha$-thalassemia syndrome. J. Pediatr. 92: 556-561.

8. Natta, C. 1978. Failure of the $\alpha$-thalassemia gene to decrease the severity of sickle cell anemia. Blood. 51: 11631168.

9. DeSimone, J., L. Kleve, M. A. Longley, and J. Shaeffer.
1974. Unbalanced globin chain synthesis in reticulocytes of sickle cell trait individuals with low concentrations of hemoglobin S. Biochem. Biophys. Res. Commun. 59: 564-569.

10. Steinberg, M. H., J. G. Adams, and B. J. Dreiling. 1975. Alpha thalassaemia in adults with sickle-cell trait. $B r . J$. Haematol. 30: 31-37.

11. Shaeffer, J. R., J. DeSimone, and L. J. Kleve. 1975. Hemoglobin synthesis studies of a family with $\alpha$-thalassemia trait and sickle cell trait. Biochem. Genet. 13: 783-788.

12. Huisman, T. H. J. 1977. Trimodality in the percentages of $\beta$ chain variants in heterozygotes: the effect of the number of active $\mathrm{Hb}_{\alpha}$ structural loci. Hemoglobin. 1: 349-382.

13. Brittenham, G. 1977. Genetic model for observed distributions of proportions of haemoglobin in sickle-cell trait. Nature (Lond.). 268: 635-636.

14. Nathan, D. G., and R. B. Gunn. 1966. Thalassemia: the consequences of unbalanced hemoglobin synthesis. Am. J. Med. 41: 815-830.

15. Fessas, $P$., and $X$. Yataganas. 1968. Intraerythroblastic instability of hemoglobin $\beta_{\mathbf{4}}$ ( $\left.\mathbf{H g b ~ H}\right)$. Blood. 31: 323-331.

16. Yataganas, X. and P. Fessas. 1969. The pattern of hemoglobin precipitation in thalassemia and its significance. Ann. N. Y. Acad. Sci. 165: 270-287.

17. Schmidt, R. M., and E. M. Brosious. 1976. Basic Laboratory Methods of Hemoglobinopathy Detection. U. S. Department of Health, Education, and Welfare, Center for Disease Control, 8th edition. DHEW Publication No. (CDC) 76-8266.

18. Huisman, T. H. J., W. A. Schroeder, A. N. Brodie, S. M. Mayson, and J. Jakway. 1975. Microchromatography of hemoglobins. III. A simplified procedure for the determination of hemoglobin $\mathrm{A}_{2}$. J. Lab. Clin. Med. 86: 700702.

19. Betke, K., H. R. Marti, and I. Schlicht. 1959. Estimation of small percentage of foetal hemoglobin. Nature (Lond.). 184: $1877-1878$.

20. Kan, Y. W., E. Schwartz, and D. G. Nathan. 1968. Globin chain synthesis in the alpha thalassemia syndromes. $J$. Clin. Invest. 47: 2515-2522.

21. Atwater, J., and E. Schwartz. 1977. Separation of hemoglobins. In Hematology. W. J. Williams, editor. McGrawHill Book Co., New York. 2nd edition. A7: 1597-1599.

22. Basset, P., Y. Beuzard, M. C. Garel, and J. Rosa. 1978. Isoelectric focusing of human hemoglobin: its application to screening, to the characterization of 70 variants, and to the study of modified fractions of normal hemoglobins. Blood. 51: 971-982.

23. Schroeder, W. A., L. A. Pace, and T. H. J. Huisman. 1976. Chromatography of hemoglobins on CM-cellulose with Bis-tris and sodium chloride developers. J. Chromatogr. 118: 295-302.

24. Salmon, J. E., U. Nudel, G. Schiliro, C. L. Natta, and A. Bank. 1978. Quantitation of human globin chain synthesis by cellulose acetate electrophoresis. Anal. Biochem. 91: 146-157.

25. Bainton, D. F., J. L. Ullyot, and M. G. Farquhar. 1971. The development of neutrophilic polymorphonuclear leukocytes in human bone marrow. J. Exp. Med. 134: 907934.

26. Taylor, J. M., A. Dozy, Y. W. Kan, H. E. Varmus, L. E. Lie-Injo, J. Ganesan, and D. Todd. 1974. Genetic lesion in homozygous $\alpha$ thalassaemia (hydrops fetalis). Nature (Lond.). 251: 392-393.

27. Kan, Y. W., A. M. Dozy, H. E. Varmus, J. M. Taylor, J. P. Holland, L. E. Lie-Injo, J. Ganesan and D. Todd. 1975. Deletion of $\alpha$-globin genes in haemoglobin- $\mathrm{H}$ disease 
demonstrates multiple $\alpha$-globin structural loci. Nature (Lond.). 255: 255-256.

28. Dozy, A. M., H. Kabisch, J. Baker, H. M. Koenig, S. Kurachi, G. Stamatoyannopoulos, D. Todd, and Y. W. Kan. 1977. The molecular defects of $\alpha$-thalassemia in the Filipino. Hemoglobin. 1: 539-546.

29. Kan, Y. W., M. S. Golbus, and A. M. Dozy. 1976. Prenatal diagnosis of $\alpha$-thalassemia. N. Engl. J. Med. 295: 11651167.

30. Kan, Y. W., and A. M. Dozy. 1978. Polymorphism of DNA sequence adjacent to human $\beta$-globin structural gene: relationship to sickle mutation.Proc. Natl.Acad.Sci.U.S.A. 75: $5631-5635$.

31. Southern, E. M. 1975. Detection of specific sequences among DNA fragments separated by gel electrophoresis. J. Mol. Biol. 98: 503-517.

32. Schwartz, E. 1974. Abnormal globin synthesis in thalassemic red cells. Semin. Hematol. 11: 549-567.

33. Beuzard, Y., M. Tulliez, J. Breton-Gorius, C. Griscelli, A. Cosson, and G. Schaison. 1978. Beta thalassemia with reticulocytopenia: clinical, biochemical, and ultrastructural studies. Blood Cells 4: 269-286.

34. Bessis, M. 1973. The erythrocyte series. In Living Blood Cells and Their Ultrastructure. Springer-Verlag New York Inc., New York. 231-233.

35. Polliack, A., and E. A. Rachmilewitz. 1973. Ultrastructural studies in $\beta$-thalassaemia major. Br. J. Haematol. 24: 319326.

36. O'Brien, R. T. 1973. The effect of iron deficiency on the expression of hemoglobin H. Blood. 41: 853-856.

37. Friedman, S., J. Atwater, and E. Schwartz. 1972. Hemoglobin Bart's and alpha thalassemia in the Negro newborn. Pediatr. Res. 6: 106.

38. Cividalli, G., and E. A. Rachmilewitz. 1977. Globin synthesis in bone marrow cells of patients with $\alpha$ - and $\beta$ thalassemia. Isr. J. Med. Sci. 13: 1246.

39. Embury, S. H., R. V. Lebo, A. M. Dozy, and Y. W. Kan.
1979. Organization of the $\alpha$-globin genes in the Chinese $\alpha$-thalassemia syndromes. J. Clin. Invest. 63: 1307-1310.

40. Dozy, A. M., Y. W. Kan, H. M. Koenig, and S. H. Embury. 1979. Alpha globin gene organization in Blacks precludes the severe form of $\alpha$ thalassemia. Clin. Res. In press.

41. Schwartz, E., and J. Atwater. 1972. $\alpha$-thalassemia in the American Negro. J. Clin. Invest. 51: 412-418.

42. Bellevue, R., H. Dosik, and R. F. Rieder. 1979. Alpha thalassaemia in American blacks: a study of a family with five cases of haemoglobin $\mathrm{H}$ disease. $\mathrm{Br}$. J. Haematol. 41: 193-202.

43. Huisman, T. H. J. 1960. Properties and inheritance of the new fast hemoglobin type found in umbilical cord blood samples of Negro babies. Clin. Chim. Acta. 5: 709-718.

44. Kan, Y. W., and D. G. Nathan. 1970. Mild thalassemia: the result of interactions of alpha and beta thalassemia genes. J. Clin. Invest. 49: 635-642.

45. Bate, C. M., and G. Humphries. 1977. Alpha-beta thalassemia. Lancet. I: 1031-1034.

46. Wasi, P., M. Sookanek, S. Pootrakul, S. Na-Nakorn, and A. Suingdumrong. 1967. Haemoglobin E and $\alpha$-thalassaemia. Br. Med. J. 4: 29-32.

47. Shaeffer, J. R., R. E. Kingston, M. J. McDonald, and H. F. Bunn. 1978. Competition of normal $\beta$ chains and sickle haemoglobin $\beta$ chains for $\alpha$ chains as a post-translational control mechanism. Nature (Lond.). 276: 631-633.

48. Abraham, E. C., and T. H. J. Huisman. 1977. Differences in affinity of variant beta chains for alpha chain: a possible explanation for the variation in the percentages of beta chain variants in heterozygotes. Hemoglobin. 1: 861-873.

49. Bank, A., G. Mears, R. Weiss, J. V. O'Donnell, and C. Natta. 1974. Preferential binding of $\beta^{s}$ globin chains associated with stroma in sickle cell disorders. J. Clin. Invest. 54: 805-809.

50. Fessas, P. 1963. Inclusions of hemoglobin in erythroblasts and erythrocytes of thalassemia. Blood. 21: 21-32. 